\title{
The Effect of Government Expenditure on Private Consumption: Evidence from China
}

\author{
Yang Chen ${ }^{1}$, Fushu Luan ${ }^{2}$ and Weihong Huang ${ }^{3 *}$
}

1 International Business School Suzhou, Xi'an Jiaotong-Liverpool University, China

${ }^{2}$ Economics Department, University of Warwick, England

${ }^{3}$ Economics Division, School of Humanities and Social Sciences, Nanyang Technological University, Singapore

\begin{abstract}
This paper employs the panel unit root tests and dynamic OLS (DOLS) estimator based on 29 provinces of China between 1996 and 2013 to estimate the relationship between government spending and private consumption with/without disposable income. It is shown that i) an increase in the aggregate level of government spending has a positive effect on private consumption; ii) a rise in the spending on economic construction and administrative management has a negative impact on private consumption while the spending on culture and education crowds in private consumption.
\end{abstract}

Keywords: Government spending; Private consumption; Disposable income; Panel unit root; Panel co-integration; Dynamic OLS; Crowding-out; Crowding-in

\section{Introduction}

The "investment-driven, export-led" model has long been adopted by Chinese government to promote economic growth; however, investment is a derived demand for consumption, and if there is no consumption support, investment then turns out to be ineffective. In addition, net exports also cannot sustain the demand in support of the long-term economic growth because it is influenced easily by the economic condition of international trading partners and international trade frictions [1]. On the contrary, private consumption is arguably a more stable component of economic growth and that is why it is relevant to this study.

Since the global economic crisis of 2008-2011, the low level of private consumption in China has been seen as a factor holding back economic development. Government spending, as a method of income redistribution, has a significant effect on private consumption. Thus the main concern in this paper is whether and to what extent the government spending stimulates private consumption. We are particularly interested in studying the effect of aggregate government fiscal expenditure on private consumption in China.

We collect data from 29 provinces in China from the China Statistical Yearbook over the period 1996-2013. The issue of nonstationary is addressed by applying a panel data version of the dynamic OLS estimator developed by Stock and Watson [2]. It is shown that an increase in the aggregate government spending is expected to crowd in private consumption. And when the model is further discomposed to incorporate the three different components of government spending, such as government spending on economic construction, culture and education as well as administrative management, we find that the spending on culture and education is complementary to private consumption, whereas, both spending on economic construction and administrative management have a negative impact on private consumption. Finally, some policy suggestions are provided.

\section{Theoretical Framework and Empirical Strategy}

Following the standard Keynesian model by maximizing the household's lifetime utility subject to the budget constraint and rearranging the Euler equation, we start the analysis based on the estimable econometric equation $C_{t}=\alpha_{0}+\alpha_{1} G_{t}+v_{t}$ Bailey [3].

To broaden heterogeneity among individual members and control for omitted variable bias, panel data approach is adopted to identify the parameters of concern with additional information from cross-sectional units [4,5]. Besides, according to Graham [6], the estimation of the association between government spending and private consumption could be biased if the disposable income is excluded from the model [7]. Thus, we estimate the modified model as below,

$$
\ln C_{i t}=\alpha_{i 0}+\alpha_{1 a} \ln G_{i t}+\beta \ln Y_{i t}{ }^{d}+v_{i t}
$$

Where $\alpha_{i 0}$ is the intercept for each unit; $\alpha_{1 a}$ is the coefficient for each independent variable; $C_{i t}$ is the private consumption; $Y^{d}$ denotes the disposable income; $G_{i t}$ represents government spending; $v_{i t}$ is the error term. We equally apply the panel data model above to the case including the different components of government expenditure given by,

$$
\ln C_{i t}=\alpha_{i 0}+\alpha_{1} \ln G_{1 i t}+\alpha_{2} \ln G_{2 i t}+\alpha_{3} \ln G_{3 i t}+\beta \ln Y_{i t}^{d}+v_{i t}
$$

Where $\mathrm{G}_{1 \mathrm{it}}$ is government expenditure on economic construction; $G_{2 i t}$ denotes government spending on culture and education and $G_{3 i t}$ represents government spending on administrative management. In terms of empirical strategy, we conduct the panel unit root tests, panel co-integration tests to deal with the non-stationary time series and then successfully identify the panel dynamic OLS estimator. The main results are summarized shows in the Tables.

\section{Concluding Remarks}

The results confirm the evidence of the crowding-in effect between

${ }^{*}$ Corresponding author: Weihong Huang, Economics Division, School of Humanities and Social Sciences, Nanyang Technological University, Singapore, E-mail: awhhuang@ntu.edu.sg

Received September 27, 2014; Accepted September 29, 2014; Published October 07, 2014

Citation: Chen Y, Luan F, Huang W (2014) The Effect of Government Expenditure on Private Consumption: Evidence from China. J Glob Econ 2: 120. doi:10.4172/2375-4389.1000120

Copyright: ( $) 2014$ Chen Y, et al. This is an open-access article distributed unde the terms of the Creative Commons Attribution License, which permits unrestricted use, distribution, and reproduction in any medium, provided the original author and source are credited. 
Citation: Chen Y, Luan F, Huang W (2014) The Effect of Government Expenditure on Private Consumption: Evidence from China. J Glob Econ 2: 120. doi: $10.4172 / 2375-4389.1000120$

Page 2 of 2

\begin{tabular}{|c|c|c|c|}
\hline \multicolumn{2}{|c|}{ Model 1 } & \multicolumn{2}{c|}{ Model 2 } \\
\hline Variable & LG & LG & LYD \\
\hline Coefficient & 1.117792 & 0.264216 & 0.704046 \\
\hline Std. Error & 0.007992 & 0.036805 & 0.028442 \\
\hline t-Statistic & 139.8644 & 7.178705 & 24.75374 \\
\hline Prob. & 0.0000 & 0.0000 & 0.0000 \\
\hline R-squared & 0.885108 & & 0.986964 \\
\hline Adjusted R-squared & 0.841224 & & 0.978709 \\
\hline
\end{tabular}

Note: Dependent variable: LCON, and fixed leads and lags specification (lead=I $\mathrm{ag}=1)$.

Table 1: Panel Dynamic Least Squares (DOLS)-Model 1 \& Model 2.

\begin{tabular}{|c|c|c|c|c|}
\hline Variable & Coefficient & Std. Error & t-Statistic & Prob. \\
\hline LG1 & -0.120918 & 0.078731 & -1.535837 & 0.1261 \\
\hline LG2 & 0.743717 & 0.151522 & 4.908318 & 0.0000 \\
\hline LG3 & -0.409238 & 0.10765 & -3.801569 & 0.0002 \\
\hline LYD & 0.780101 & 0.013445 & 58.02252 & 0.0000 \\
\hline \multicolumn{3}{|c|}{ R-squared: 0.995109} & Adjusted R-squared: 0.987447 \\
\hline
\end{tabular}

Note: Fixed leads and lags specification (lead=1, lag=1)

Table 2: Panel Dynamic OLS with $Y^{d}$.

\begin{tabular}{|c|c|c|c|c|}
\hline Variable & Coefficient & Std. Error & t-Statistic & Prob. \\
\hline LG1 & 0.264464 & 0.392246 & 0.67423 & 0.5008 \\
\hline LG2 & 3.806409 & 0.607811 & 6.26249 & 0.0000 \\
\hline LG3 & -2.842019 & 0.485559 & -5.853085 & 0.0000 \\
\hline \multicolumn{2}{|c|}{ R-squared: 0.693745} & Adjusted R-squared: 0.388663 \\
\hline
\end{tabular}

Note: Fixed leads and lags specification (lead=1, lag=1).

Table 3: Panel Dynamic OLS without $Y^{d}$ aggregate level of government spending and private consumption $\left(\alpha_{1 a}=0.26\right.$ in Table 1). Furthermore, we have also assessed the effects of different types of government spending on private consumption. The significant coefficients $\left(\alpha_{1}=-0.121, \alpha_{2}=0.744\right.$ and $\alpha_{3}=-0.409$ in Tables 2 and 3) of the three different types of government spending imply that government spending on culture and education and private consumption are complements. Alternatively, there is a significant degree of substitutability between government expenditure on economic construction and private consumption, as well as between government expenditure on administrative management and private consumption respectively.

From a policy standpoint, the reported estimates seem to suggest that government can improve economic performance in the long run by raising the investment in education, culture and health, and in the meantime control the administrative expenditure in a more reasonable way. In addition, it will be interesting to group the 29 provinces in China into different regions and compare the varied impacts of government expenditure by region controlling the size of the government and the degree of economic growth.

\section{References}

1. Razmi A (2008) Is the Chinese investment- and export-Led growth model sustainable? Some rising concerns.

2. Stock JH, Watson M (1993) A simple estimator of co-integrating vectors in higher order integrated systems. Econometrica 61: 783-820.

3. Bailey MJ (1971) National income and the price level. McGraw-Hill New York.

4. Baltagi B (1995) Econometric analysis of panel data. Wiley New York.

5. Hsiao C (1996) Analysis of panel data. Cambridge Univ Press Cambridge.

6. Graham FC (1993) Fiscal policy and aggregate demand: comment. American Economic Review 83: 659-666.

7. Ho T (2001) The government spending and private consumption: A panel integration analysis. Int Rev Econ Financ 10: 95-108. 